\title{
First record of Marteilia sp. in mussels Mytilus galloprovincialis in Croatia
}

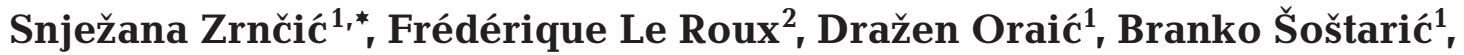 \\ Franck C. J. Berthe ${ }^{2}$
}

${ }^{1}$ Croatian Veterinary Institute, Department of Fish Diseases and Aquaculture, Savska 143, 10000 Zagreb, Croatia

${ }^{2}$ IFREMER, Laboratoire de Génétique et Pathologie, BP 133, 17390 La Tremblade, France

\begin{abstract}
Marteiliosis is a disease of molluscs caused by Marteilia refringens in Europe and $M$. sydneyi in Australia. During routine examination of cultured mussels Mytilus galloprovinciallis in the northern Adriatic, the occurrence of Marteilia sp. was recorded with a prevalence of $5 \%$. This parasite was not detected in flat oysters reared in the same area. The affiliation of the detected parasite in M. galloprovinciallis was confirmed by in situ hybridization using a $M$. refringens probe, specific at the genus level. DNA of these infected mussels originating from the same area will be used to clarify the taxonomic position of this species within the genus Marteilia using a molecular approach.
\end{abstract}

KEY WORDS: Marteilia maurini $\cdot$ Parasite $\cdot$ Mytilus galloprovincialis $\cdot$ Detection · Taxonomy

\section{INTRODUCTION}

Marteiliosis is a disease of molluscs caused by protistan parasites of the genus Marteilia, phylum Paramyxea (Desportes \& Perkins 1990, OIE 1997, Berthe et al. 2000). Marteilia refringens is the etiological agent of the 'Aber disease' (Grizel et al. 1974) and this pathogen has caused mass mortalities in the European flat oyster Ostrea edulis industry (Alderman 1979, Robert et al. 1991). Similarly, a related organism, Marteilia sydneyi, is responsible for mass mortalities of Saccostrea commercialis in Australia (Perkins \& Wolf 1976, Adlard \& Ernst 1995). The diagnosis of these 2 species can easily be achieved by classical histological methods. $M$. sydneyi may be distinguished from $M$. refringens by the number of secondary and tertiary cells in the characteristic cell-within-cell structure of these parasites (Table 1).

In Europe, Marteilia refringens was observed in Ostrea edulis (Grizel et al. 1974), in Mytilus edulis and M. galloprovincialis (Tigé \& Rabouin 1976, Villalba et

*E-mail: zrncic@rudjer.irb.hr al. 1993). M. refringens cells were also found accidentally in the Pacific cup oyster Crassostrea gigas (Cahour 1979). Another species of the genus Marteilia, M. maurini, was described in mussels M. galloprovincialis imported to France from Venice lagoon in Italy (Comps et al. 1982) as well as in M. edulis from France (Auffret \& Poder 1985). Marteilia sp. was observed in cockles Cardium edule, clams Tapes rhomboides and T. pullastra (Comps et al. 1975, Poder et al. 1983, Figueras et al. 1996), and in mussels Modiolus modiolus, Mytilus edulis, and M. galloprovincialis (Comps

Table 1. Number of secondary, tertiary and sporoplasm cells in tertiary cells of paramyxean genera and species. ND: not determined

\begin{tabular}{|lccc|}
\hline Species & $\begin{array}{c}\text { No. of } \\
\text { secondary } \\
\text { cells }\end{array}$ & $\begin{array}{c}\text { No. of } \\
\text { tertiary } \\
\text { cells }\end{array}$ & $\begin{array}{c}\text { No. of } \\
\text { sporoplasm } \\
\text { cells }\end{array}$ \\
\hline Marteilia refringens & 8 & $3-4$ & 3 \\
Marteilia sydneyi & $8-16$ & $2(3)$ & 3 \\
Marteilia lengehi & 8 & $?$ & ND \\
Marteilia maurini & 8 & $3-4$ & 3 \\
Marteilia christenseni & 8 & 4 & 3 \\
\hline
\end{tabular}


et al. 1975, Poder et al. 1983, Auffret \& Poder 1985, Ceschia et al. 1991, Figueras et al. 1991). Lastly, the species Marteilia christenseni was described in Scrobicularia piperata P. (Comps 1983) from the Atlantic coast of France.

The differential diagnosis of the 2 main species of Marteilia reported in Europe ( $M$. refringens and $M$. maurini) was based on ultrastructural characteristics and host specificity (Grizel et al. 1974, Perkins 1976, Comps et al. 1982, Figueras \& Montes 1988). Because $M$. maurini had been reported only from mussels, it has been proposed that $M$. maurini should be considered as the species parasitizing mussels. However, host specificity was disputed by Villalba et al. (1993), who found Marteila refringens in Mytilus galloprovincialis. Moreover, a recent study (Longshaw pers. comm.) has challenged the criteria used for the identification of species within the genus Marteilia (Perkins 1976, Perkins \& Wolf 1976, Comps et al. 1982, Auffret \& Poder 1985). It was concluded that $M$. maurini from Mytilus edulis and M. galloprovincialis cannot be separated from $M$. refringens from Ostrea edulis using current ultrastructural criteria. Sequencing genes of taxonomic value may help to resolve the taxonomic position of $M$. refringens and its relatives. Therefore this may assist in determining if $M$. maurini really is a different species from $M$. refringens (Berthe et al. in press).

In this paper we document the first record of marteiliosis in mussels Mytilus galloprovincialis from Croatian shellfish farms. Taxonomic implications of this finding will be discussed.

\section{MATERIALS AND METHODS}

The origin of the molluscs included in the study. The 2 shellfish farms included in the study are located on the northern Adriatic peninsula of Istra. The first farm is located on the eastern coast of Istra in Raša Bay, and the second is on the western coast of Istra in Limski Bay (Fig. 1). Both farms cultivate mussels on rafts, while in the Limski Bay mussels and oysters are cultivated on the same rafts.

One hundred and fifty Mytilus galloprovincialis mussels were sampled from the first shellfish farm and 150 M. galloprovincialis mussels and 100 Ostrea edulis oysters were sampled from the second farm at the end of August 1998 and 1999, respectively.

Cytological procedures. Molluscs from each batch were checked for the presence of Marteilia spp. by means of digestive gland imprints. Imprints were stained using a Giemsa-modified staining method (Hemacolor Kit, Merck). Results were confirmed by histology and in situ hybridization.

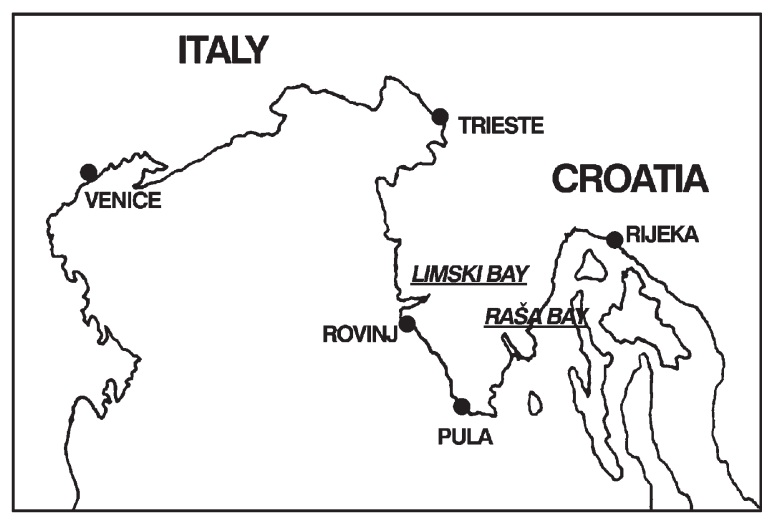

Fig. 1. Shellfish farms included in the study are situated on the eastern and western coast of the Istra peninsula in the northern Adriatic, close to the Venice lagoon, where Marteilia maurini was first described in Mytilus galloprovincialis

Histological procedures. The visceral masses of the mussels were cut along the sagittal plane and placed in Davidson's fixative AFA (10\% glycerine, $20 \%$ formalin, 30\% 95\% ethanol, 30\% $\mathrm{dH}_{2} \mathrm{O}, 10 \%$ glacial acetic acid) for at least $24 \mathrm{~h}$. The sections were subsequently treated by conventional histological procedures. Sections were cut $2 \mu \mathrm{m}$ thick and stained with hematoxylin and eosin.

Preparation of the probe for in situ hybridization. The probe was labelled with digoxigenin by PCR using primers designed in the SSU rDNA gene specifics for Marteilia refringens (SS2/SAS1) and DNA of Marteilia sp.-infected Mytilus galloprovincialis from Croatia as the target (Le Roux et al. 1999). DNA from infected mussels was extracted according to standard protocols using Proteinase K, phenol chloroform and a precipitation of ethanol. PCR was performed in $50 \mu \mathrm{l}$ with about $10 \mathrm{ng}$ of purified DNA mixed with $5 \mu \mathrm{l}$ of PCR buffer 10X, $5 \mu \mathrm{l}$ of $\mathrm{MgCl}_{2} 25 \mathrm{mM}, 5 \mu \mathrm{l}$ of dNTP $2 \mathrm{mM}, 1 \mu \mathrm{l}$ of DIG-dUTP $25 \mathrm{mM}, 0.5 \mu \mathrm{l}$ of each primer $100 \mu \mathrm{M}$ and $0.25 \mu l$ (1 unit) of Taq DNA polymerase (Promega). Samples were overlaid with mineral oil, denatured for $5 \mathrm{~min}$ at $94^{\circ} \mathrm{C}$ and amplified by 30 cycles: $1 \mathrm{~min}$ at $94^{\circ} \mathrm{C}$ for denaturation, $1 \mathrm{~min}$ at $55^{\circ} \mathrm{C}$ for primers annealing, and $1 \mathrm{~min}$ at $72^{\circ} \mathrm{C}$ for elongation in a thermal cycle apparatus (MJ Research). Polymerisation at $72^{\circ} \mathrm{C}$ was then extended for 10 min to ensure complete elongation of the amplified products. The labelling of the probe was confirmed after electrophoresis of the PCR products in $1 \%$ agarose gel because labelled fragments migrate slower than unlabelled (same PCR reaction without DIG-dUTP).

In situ hybridization. For in situ hybridization, sections were cut at $5 \mu \mathrm{m}$ and placed on aminoalkylsilane coated slides (Silane-Prep Slides, Sigma) and then baked overnight in an oven at $60^{\circ} \mathrm{C}$. The sections were 
dewaxed by immersing in xylene for $10 \mathrm{~min}$. This was repeated once and then the solvent was eliminated by immersion in 2 successive absolute ethanol baths followed by 10 min air-drying.

The sections were treated with Proteinase K $(100 \mu \mathrm{g}$ $\mathrm{ml}^{-1}$ ) in TE buffer (Tris $50 \mathrm{mM}$, EDTA $10 \mathrm{mM}$ ), at $37^{\circ} \mathrm{C}$ for $30 \mathrm{~min}$. Slides were dehydrated by immersion in absolute ethanol and air-dried. Sections were prehybridized in a humid chamber for $1 \mathrm{~h}$ at $42^{\circ} \mathrm{C}$ in $500 \mu \mathrm{l}$ of $4 \times \mathrm{SSC}_{1} 50 \%$ formamide, $1 \times$ Denhardt's solution, $250 \mathrm{\mu g} \mathrm{ml}^{-1}$ yeast tRNA, $10 \%$ dextran sulphate. The solution was then replaced with $50 \mu \mathrm{l}$ hybridization mix and the buffer described above containing $10 \mathrm{ng}$ ( $1 \mu \mathrm{l}$ of the PCR reaction) of the digoxigenin-labelled probe. Sections were covered with in situ plastic coverslips and placed on heating block at $94^{\circ} \mathrm{C}$ for $5 \mathrm{~min}$. Slides were then cooled on ice for $1 \mathrm{~min}$ before overnight hybridization at $42^{\circ} \mathrm{C}$. Sections were washed twice for $5 \mathrm{~min}$ in $2 \times \mathrm{SSC}$ at room temperature, and once for $10 \mathrm{~min}$ in $0.4 \times \mathrm{SSC}$ at $42^{\circ} \mathrm{C}$. The detection steps were performed according manufacturer's instructions (Dig Nucleic Acid Detection Kit, Boehringer Mannheim).

\section{RESULTS}

No mortality of Mytilus galloprovincialis mussels or Ostrea edulis oysters has been noted at either farm.

The presence of different developmental stages of the parasite was observed in stained imprints of the mussel's digestive gland at a prevalence of $5 \%$ at both sites included in the study during 1998 and 1999 (Fig. 2).

Haematoxylin-eosin stained histological sections of the parasite within visceral mass of the mussels revealed different stages characterising the life cycle of the genus Marteilia. A variable number of presporulation vegetative stages with ovoid primary cells including 1 or more secondary cells were observed between epithelial cells of the digestive tubules (Figs. 3 \& 4).

Fig. 2. Marteilia spp. in the digestive gland imprints of Mytilus galloprovincialis. Giemsa-modified staining (Hemacolor Kit, Merck), $\times 1000$
In situ hybridization experiments performed with Marteilia sp.-infected tissue of Mytilus galloprovincialis gave a consistently strong reaction with all Marteilia sp. stages but not with the host cell nuclei (Fig. 5).

Both histological approaches (haematoxylin-eosin and in situ hybridization) showed the same prevalence of $5 \%$ for Marteilia sp. infection similar to the digestive gland imprints. Furthermore, it has to be noted that the infection was focused in only 1 region of the digestive gland. Marteilia sp was not detected in Ostrea edulis oysters from this region.

\section{DISCUSSION}

Since the late sixties, Marteilia spp. have presented a major problem for cultured oysters in Europe (Ostrea edulis) and Australia (Saccostrea commercialis) (Alderman 1979, Wolf 1979).

In Europe, Marteilia refringens has been reported from different species of oysters and mussels. The existence of another species within the genus Marteilia maurini, based on ultrastructural analysis and host specificity, has been proposed (Comps et al. 1982). The validity of this species is still controversial because a parasite can have a different morphology depending upon the host. Furthermore, when tested on a large number of samples, ultrastructural criteria failed to discriminate the 2 species, $M$. refringens and M. maurini (Longshaw pers. comm.).

The pathogenicity of Marteilia refringens for flat oysters is well documented (Alderman 1979, Balouet

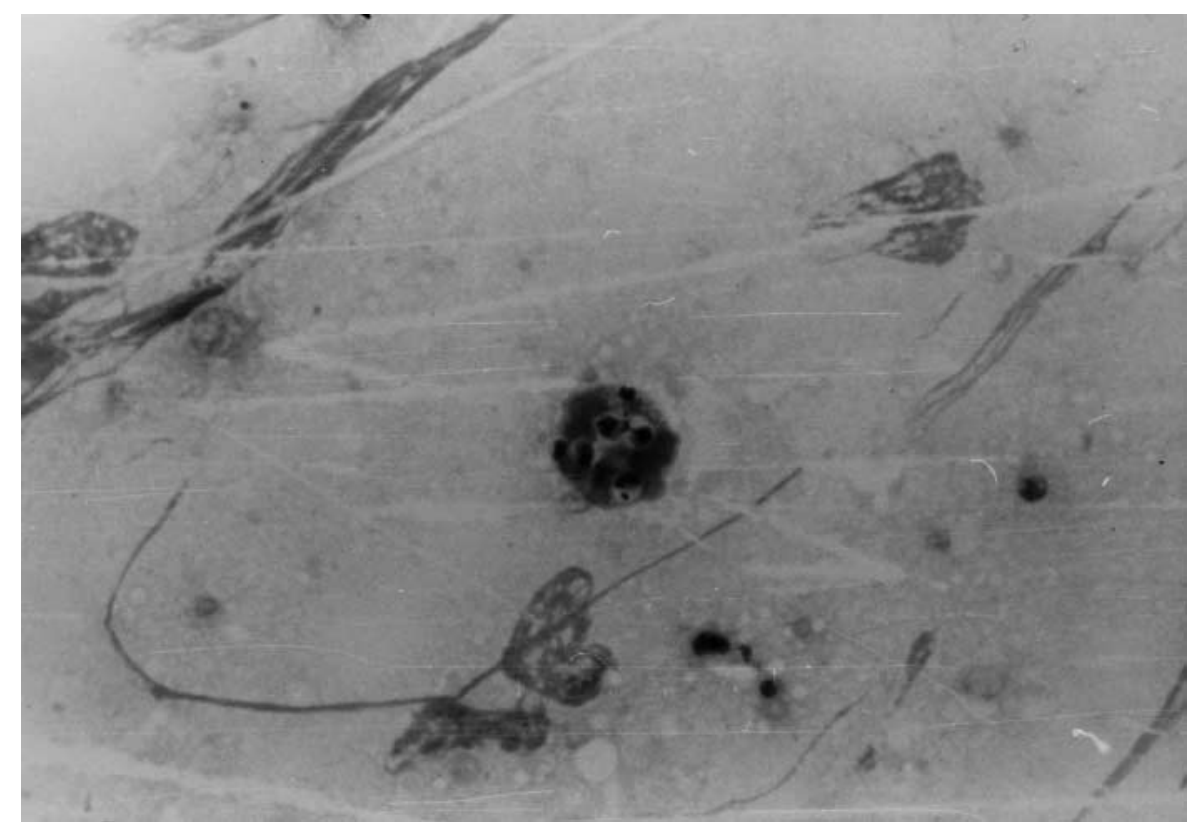


1979, Grizel 1985, Berthe et al. 1998) whereas for other bivalves and other species of the genus Marteilia the relationships between the host and the parasite are less clear.

The control of marteliosis is based mainly on the development of programs to prevent the transfer of infected stocks into areas free of the disease. With this in mind, diagnostic tools are of utmost importance. In this respect a clarification of the taxonomy is needed. For this, 3 fundamental questions are still unresolved: (1) Are there different species in the genus Marteilia in Europe (i.e. assessment of $M$. maurini)? (2) Is there any tropism and/or specificity of a parasite for a host species or geographical repartition? (3) Are there different pathogenesis of the parasite taxa?

In this paper we present the first record of marteiliosis in the Croatian shellfish cultivation facilities in a region neighbouring the site of original description of Marteilia maurini (Comps et al. 1982). Histological findings and in situ hybridization show that this parasite belongs to the genus Marteilia. Prevalence of the parasite in mussels was low, 5\%, and was constant for 1998 and 1999. We did not detect the parasite in the oyster Ostrea edulis. The very same situation was observed in Spain where, although a high prevalence $(75 \%)$ of $M$. refringens in mussels was reported, only 1 oyster was detected with a single $M$. refringens primary cell in the digestive epithelium. This might be ascribed to an accidental infection (Figueras \& Robledo 1993). This host distribution could reside

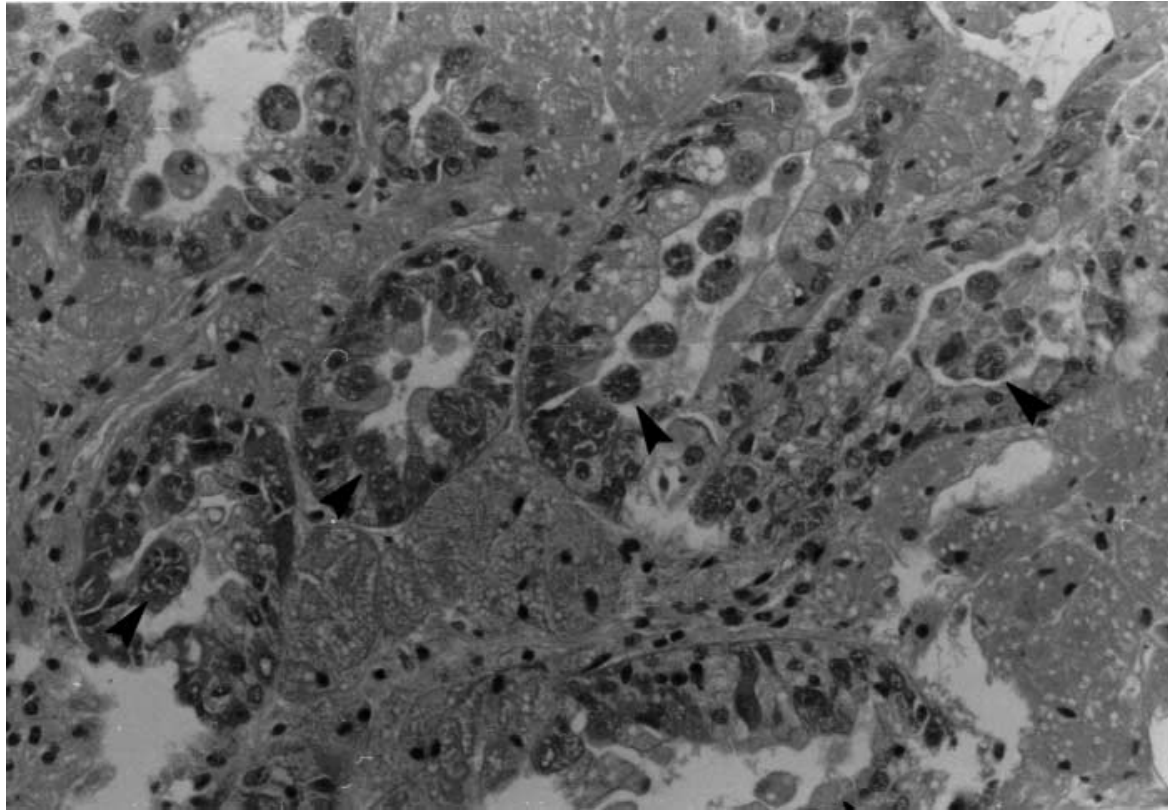

Fig. 3. Presporulation stages (arrowheads) of the genus Marteilia between epithelial cells of the digestive tubules of Mytilus galloprovincialis. H\&E staining, $\times 400$

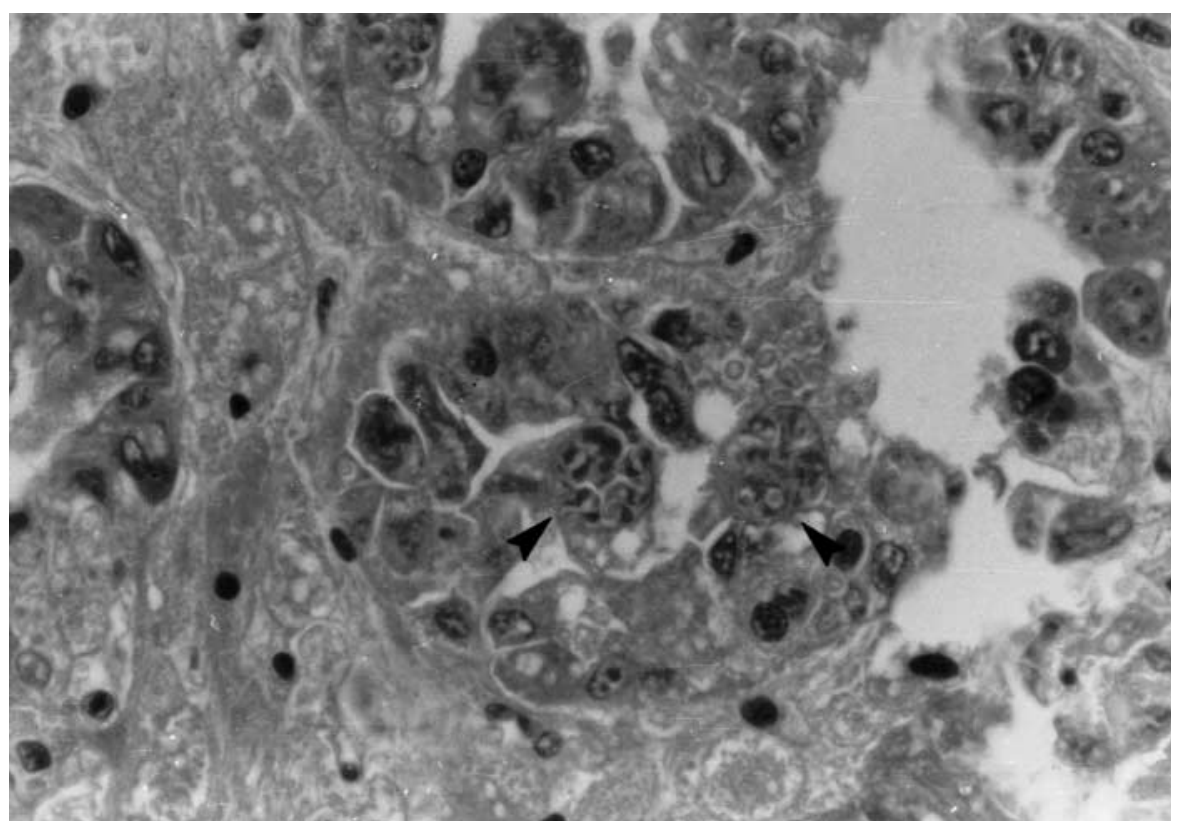

Fig. 4. Vegetative stages of Marteilia spp. showing ovoid primary cells (arrowheads) including 1 or more secondary cells. H\&E staining, $\times 1000$ in the fact that: (1) There are 2
types of Marteilia with a tropism for a specific host; (2) An intermediate host is believed to be involved in the $M$. refringens life cycle (Balouet 1979, Van Banning 1979) and, therefore, the transmission of Marteilia from mussels to oysters requires a distinct intermediate host not present in this area; (3) Oysters from the 2 samples examined could be resistant to $M$. refringens infection. However, the spat of the same species, which was obtained in a hatchery from oysters from Croatia, was transplanted and further cultivated in France (Thau pond). As a result, cultivated oysters became infected with $M$. refringens and, indeed, had a high 
Fig. 5. Detection of the Marteilia spp. by in situ hybridization performed with infected tissues of Mytilus galloprovincialis. $\times 400$

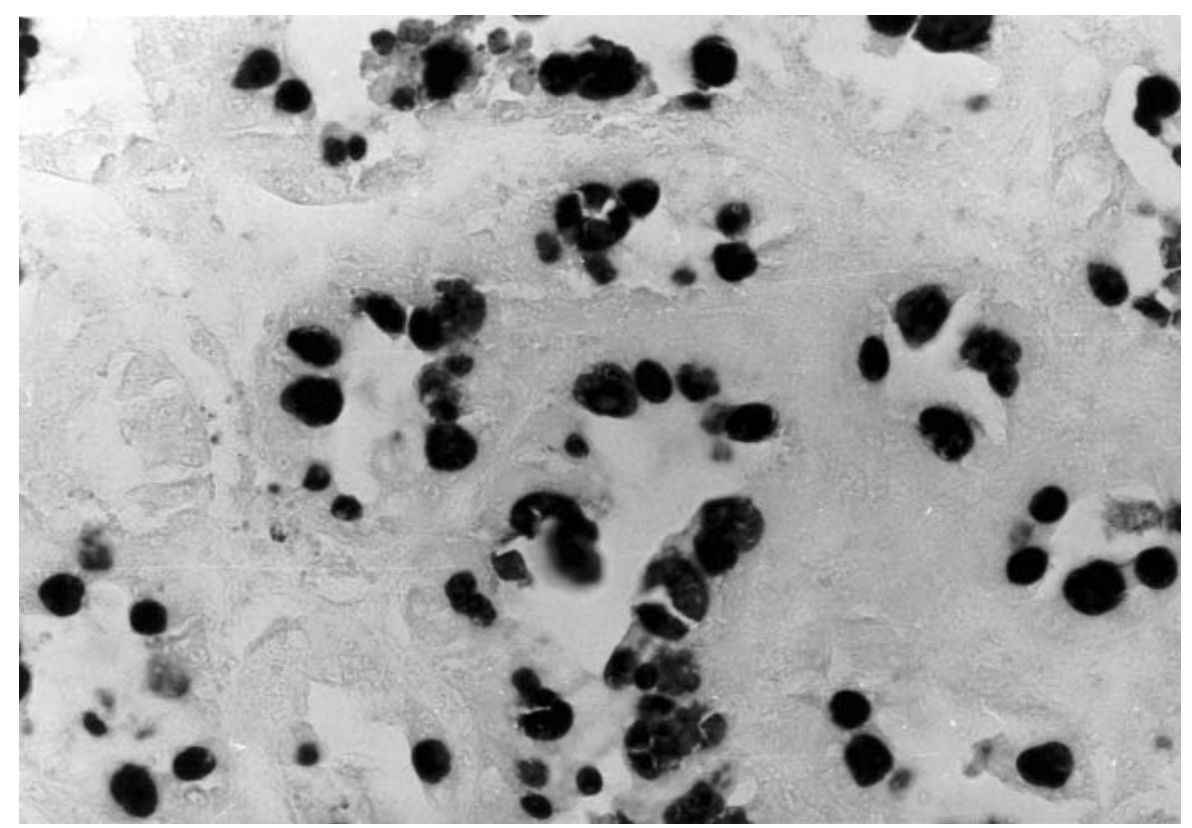

prevalence of this disease. Based on these facts, we presume that flat oysters originating from Croatia are more sensitive to this parasite than flat oysters from France (Y. Pichot pers. comm.).

Determination of the species within the genus Marteilia detected in Croatia will require additional research. Because ultrastructural data has recognised limitations (i.e. morphology depending on the host), DNA sequencing of genes with taxonomic value will help clarify the controversial taxonomy of $M$. refringens and its relatives. Sequence comparison of ribosomal genes has given new insights into molecular and cellular evolution. These genes contain sufficient evolutionary information to allow measurement of both close and distant phylogenic relationships (Sogin \& Gunderson 1987). In a previous work the small ribosomal gene subunits (SSU rDNA) of Marteilia, purified from infected Mytilus edulis mussels, and Ostrea edulis oysters, were sequenced and shown to be identical (Berthe et al. in press). Therefore, on the basis of the SSU rDNA sequence it is impossible to distinguish Marteilia spp. parasiting oysters and mussels. However, doubt persists regarding the existence of a second species of Marteilia. Namely, M. maurini was first described in Mytilus galloprovincialis originating from the Venice lagoon (Comps et al. 1982). Therefore, M. maurini could be truly indigenous to this geographic area. To answer this question, the sequence of the SSU rDNA gene of Marteilia sp. infecting M. galloprovincialis from the Adriatic Sea is needed. Therefore, the parasite detected in Croatia will provide a precious source of parasite that can be used in a molecular approach to determine if this parasite is truly a different species.
Acknowledgements. This study was partially funded by the EU DG XIV (contract FAIR CT: PL97-3640) and the EU DG VI through the Community Reference Laboratory for Mollusc Diseases, Ifremer, La Tremblade. The authors thank Yves Pichot (Laboratoire Conchylicole de Méditerrannée) for his unpublished information.

\section{LITERATURE CITED}

Adlard RD, Ernst I (1995) Extended range of the oyster pathogen Marteilia sydneyi. Bull Eur Assoc Fish Pathol 15:119-121

Alderman DJ (1979) Epizootiology of Marteilia refringens in Europe. Mar Fish Rev 41(1-2):67-69

Auffret M, Poder M (1985) Recherches sur Marteilia maurini, parasite de Mytilus edulis sur les côtes de Bretagne nord. Rev Trav Inst Pêches Marit 47:105-109

Balouet G (1979) Marteilia refrigens-considerations of the life cycle and development of Aber disease in Ostrea edulis. Mar Fish Rev 41(1-2):64-66

Berthe FCJ, Pernas M, Zerabib N, Haffner P, Thebault A, Figueras AJ (1998) Experimental transmission of Marteilia refrigens with special consideration of its life cycle. Dis Aquat Org 34:135-144

Berthe FCJ, Le Roux F, Peyretaillade E, Peyret P, Rodriguez D, Gouy M, Vivares C (2000) Phylogenetic analysis of the small subunit ribosomal RNA of Marteilia refringens validates the existence of phylum Paramyxea (Desportes and Perkins, 1990). J Eukaryot Microbiol 47(3):288-293

Cahour A (1979) Marteilia refringens and Crassostrea gigas. Mar Fish Rev 41(1-2):19-20

Ceschia G, Mion A, Orel G, Giorgetti G (1991) Parasitological studies in mussel culture in Friuli-Venezia Giulia. Hydrores Inf 8:5-12

Comps M (1983) Etude morphologique de Marteilia christenseni sp. n. parasite du lavignon Scrobicularia piperata P. (Mollusque pélécypode). Rev Trav Inst Pêches Marit 47: 99-104 
Comps M, Grizel H, Tigé G, Duthoit JL (1975) Parasites nouveaux de la glande digestive des mollusques marins Mytilus edulis L. et Cardium edule. C R Acad Sci Sér D 281:179-181

Comps M, Grizel H, Papayanni Y (1982) Infection parasitaire causée par Marteilia maurini sp. nov. chez la moule Mytilus galloprovincialis. J Cons Int Explor Mer F:1-3

Desportes I, Perkins FO (1990) Phylum paramyxea. In: Margulis L, Corliss JO, Melkonian M, Chapman DJ (eds) Handbook of prototista. Jones and Bartlett Publishing Corporation, Boston, p 30-35

Figueras AJ, Montes J (1988) Aber disease of edible oysters caused by Marteilia refringens. Am Fish Soc Spec Publ 18:38-46

Figueras AJ, Robledo JAF (1993) Does Marteilia present in mussels (Mytilus galloprovinciallis) infect flat oysters (Ostrea edulis)? Bull Eur Assoc Fish Pathol 13:97-99

Figueras AJ, Jardon CF, Caldas JR (1991) Diseases and parasites of rafted mussels (Mytilus galloprovincialis Lmk): preliminary results. Aquaculture 99:17-33

Figueras AJ, Robledo JAF, Novoa B (1996) Brown ring disease and parasites in clams (Ruditapes decussatus and $R$. philippinarum) from Spain and Portugal. J Shellfish Res 15(2):363-368

Grizel H (1985) Etude des recentes epizooties de l'huitre plate (Ostrea edulis Linne) et leur impact sur l'ostreiculture bretonne. Thèse Sciences et Techniques du Languedoc, Académie de Montpellier

Grizel H, Comps M, Bonami JR, Cousserans F, Duthoit JL, Le Pennec MA (1974) Recherche sur l'agent de la maladie de la glande digestive de Ostrea edulis Linne. Sci Pêche, Bull Inst Pêches Marit 240:7-29

Le Roux F, Audermard C, Barnaud A, Berthe F (1999) DNA probes as potential tools for detection of Marteilia refringens. Mar Biotechnol 1:6

OIE (1997) Code sanitaire international pour les animaux

Editorial responsibility: Albert Sparks, Seattle, Washington, USA aquatiques. OIE Fish Diseases Commission (ed) Office International des Epizooties, Paris, p 105-108

Perkins FO (1976) Ultrastructure of sporulation in the European flat oyster pathogen Marteilia refringens-taxonomic implications. J Protozool 23:64-74

Perkins FO, Wolf PH (1976) Fine structure of Marteilia sydneyi sp. n.- haplosporidian pathogen of Australian oysters. J Parasitol 62:528-538

Poder M, Auffret M, Balouet G (1983) Etudes pathologiques et épidemiologiques des lésions parasitaires chez Ostrea edulis L. - premiers résultats d'une recherche prospective comparative chez les principales espèces de mollusques des zones ostréicoles de Bretagne nord. In: CNRS-CNEXO (eds) Colloque sur les bases biologiques de l'aquaculture, Dec 12-16, 1983. CNRS-CNEXO, Montpellier, p 125-138

Robert R, Borel M, Pichot Y, Trut G (1991) Growth and mortality of the European oyster Ostrea edulis in the Bay of Arcachon (France). Aquat Living Resour 4:265-274

Sogin ML, Gunderson JH (1987) Structural diversity of eukaryotic small subunit ribosomal RNAs: evolutionary implications. Endocytobiology III. Ann NY Acad Sci 503: 125-139

Tigé G, Rabouin MA (1976) Etude d'un lot de moules transférées dans un centre touché par l'épizootie affectant l'huitre plate. J Cons Int Explor Mer K:1-10

Van Banning PJ (1979) Haplosporidian diseases of imported oysters, Ostrea edulis, in Dutch estuaries. Mar Fish Rev 41(1-2):8-18

Villalba A, Mourelle SG, López MC, Carballal MJ, Azevedo C (1993) Marteiliosis affecting cultured mussels Mytilus galloprovincialis of Galicia (NW Spain). I. Etiology, phases of the infection, and temporal and spatial variability in prevalence. Dis Aquat Org 16:61-72

Wolf PH (1979) Life cycle and ecology of Marteilia sydneyi in the Australian oyster, Crassostrea commercialis. Mar Fish Rev 41:70-72

Submitted: July 5, 2000; Accepted: October 18, 2000 Proofs received from author(s): January 22, 2001 